UDC 811.113.5 + 811.112.2 + 81'1

Ewa Data-Bukowska

Jagiellonian University in Kraków

\title{
A SOMEWHAT MORE EGOCENTRIC SISTER: A COGNITIVE GRAMMAR ACCOUNT OF NORWEGIAN HER AND GERMAN HIER AS DEICTIC SPACE BUILDERS
}

For citation: Data-Bukowska E. A somewhat more egocentric sister: A cognitive grammar account of Norwegian her and German hier as deictic space builders. Scandinavian Philology, 2020, vol. 18, issue 1, pp. 32-55. https://doi.org/10.21638/11701/spbu21.2020.103

This article draws on data from a parallel corpus (the Oslo Multilingual Corpus) to explore differences in how the cognate Norwegian and German adverbs her/hier 'here' (seemingly highly similar in meaning) are used as deictic space builders in discourse. The aim of the presented study is to propose some more general cognitive mechanisms that may underlie such differences, in the languages that are closely related. The linguistic material is considered within the framework of cognitive grammar and is linked to recent knowledge on bilingual cognition as represented in translation. By carefully examining both the sources and translations of these adverbs in the corpus of translations, we identify different patterns of construal in the languages compared. The main difference found in setting up the deictic space pertains to the construction of the coordinate system preferred in Norwegian and German - a more egocentric one in the former, and one more subjective and focused on the object of conceptualization in the latter. Thus, close scrutiny of how the two cognates behave in translation helps us to confirm that differences in imagery in two languages may be based on different preferred vantage points, resulting in some clear conceptualization patterns on a lower level, and that imagery is subject to choice of particular cultures. Additionally, it is demonstrated that Norwegian seems less space-oriented than German, which to a greater extent prefers detailed spatial indication within discourse, and that the German hier may be less proximal than the proximal her.

Keywords: cognates, deixis, indexicals, Cognitive Grammar, subjectivity, perspective, space builders, correspondences, parallel corpus, Norwegian her, German hier. 


\section{INTRODUCTION}

Cognitive Grammar (CG) ascribes an important role to spatial and visual experience, which shapes other aspects of human cognition, including language. As Ronald W. Langacker expresses it: "[u]ndoubtedly its role is both pervasive and highly important - we are first and foremost spatial and visual creatures" [Langacker, 1995, p. 153]. However, the linguistic significance of this fact is still far from being thoroughly clarified and investigated, particularly in contrastive studies, when two or more languages are concerned. One question that remains open, for instance, is whether differences in imagery [Langacker, 1987, p. 110] in two languages may be based on different vantage points that are preferred in these languages, influencing conventional ways of scene construal in them. If so, how does this function? In the present study, some aspects of this issue will be investigated based on the example of two cognate deictic adverbs/adverbials, the Norwegian her 'here' and the German hier 'here', analyzed in parallel corpus data.

The main aim of this study is to ascertain to what extent Norwegian and German, which are very closely related languages, show similarities and differences in the construction of the deictic space through the use of the seemingly highly similar adverbials her/hier in discourse, and to propose some more general cognitive mechanisms that may underlie the instances where the languages under investigation differ in imagery in this respect.

The linguistic material, drawn from a parallel corpus, will be considered within the framework of Langacker's Cognitive Grammar [Langacker, 1987], where meaning is understood as a matter of conceptualization and the search for equivalence in translation is treated as taking place on this level [Tabakowska, 1993]. Thus, it is assumed in this article that an analysis of translation data enables us to compare two (or many) ways of conceptualizing the same scene (the perceived reality) as manifested in different languages. In corpus data, such characteristics work on a larger scale and the corpus is seen as reflecting the conventions of a given society using language communicatively. Therefore, we are herein exploring certain patterns of construal in the languages compared, as identified on the basis of translations. 


\section{DEIXIS}

John Lyons defines deixis as:

the location and identification of persons, objects, events, processes and activities being talked about or referred to, in relation to the spatiotemporal context created and sustained by the act of utterance and the participation in it, typically, of a single speaker and at least one addressee [Lyons, 1977, p. 637].

Taking into account this pioneer definition of deixis, establishing the concept as the source of reference per se, Francis Cornish defines it in a modified way:

Deixis is one (very essential) way of "grounding" the discourse to be created by the production of text in some appropriate context: it is context-establishing in that it fixes the basic contextual parameters (space - time - speaker and addressee - source of viewpoint) for the communicative event, setting up the subjective viewpoint or perspective within which that discourse is to be construed and hence constructed [Cornish, 2009, p. 3, bolding E.D.-B.].

The core of deixis consists, then, in relating linguistic conceptualizations (expressions) to the constitutive elements of the spatiotemporal co-ordinates of the speech event - the egocentric origo [Bühler, 1934] or the ground [Langacker, 1987] - encompassing I, here, now (and you). Therefore, it may be stated that through the use of linguistic means of deixis, the speaker shapes a frame for a given utterance, mainly (but not exclusively) pertaining to space and time, where s/he and the addressee are co-present.

However, in the definitions above, one aspect of the concept's description may be seen as particularly important and inspiring for the present article - in Cornish's words, the idea that deixis is connected with "setting up the subjective viewpoint or perspective within which [the] discourse is to be construed". This implies that in analyzing deixis we need to know not only the constitutive elements of the speech event (the origo) functioning as reference points in communication, but also how they are conceived. As Sophia Marmaridou remarks, each deictic expression evokes a mental space, the construction of which also involves a conceptualization of the deictic centre [Marmaridou, 2000, p. 100].

Because in CG meaning is understood as a matter of conceptualization [Langacker, 1987], which always implies taking a perspective on a given scene, such points of view may be set individually, as it is in different 
linguistic portrayals applied to describe the same part of reality. On the other hand, it may be assumed that reality may be also construed in a given language from a preferred, more or less conventionalized, viewpoint applied by the speakers in conventional linguistic conceptualizations in general. Imagery is then subject to choices made from the point of view not of individual conceptualizers, but of view of particular languages. Thus, in the context of the present paper, it is assumed that particular languages have conventionalized the construal of the deictic space by setting such points of view in different manner and that their formation may be revealed by comparing languages to each other. The deictic space (or frame), which is an abstraction or mental representation of a specific physical space, may be seen as universal, yet its interpretation may be culturally determined (see e. g. [Kryk-Kastovsky, 1996]). Some deictic concepts that occur in a given language may be not present in other cultures or they may be conceptually shaped in different manners - a fact that also pertains to the construction of the origo itself.

\section{DEICTIC HER AND HIER}

The adverbs her/hier, the focus of this study, are close cognates in two closely related languages, and as such at first glance they seem very similar in terms of their meaning and usage. Both are usually classified as place-deictic expressions or indexicals, referring to concrete or abstract locations, relative to the speaker functioning as the anchor of the location. The her/hier location is the same as the speaker, even though it is to be seen as quite vague, expanding from a very precise place in a particular room to the whole universe. However, one difference is that the Norwegian her functions in a binary system encompassing her 'here' and der 'there', while the German system is based on three elements hier 'here' - dort 'there' - da 'here/there'.

Grammatical descriptions of German hier are very sparse [cf. Helbig, Buscha, 1988, p. 343]. The item is mainly classified as adverb possessing a spatial meaning, that can be used deictically and anaphorically [Ehrich, 1982, p. 45; 1992; Klein, 1978]. It is also connected with now-orientation and proximity [Blühdorn, 2002, p. 260-262, 265]. A more thorough pragmatic analysis of the uses of hier, shows, however, that the adverb can also do several varied types of discourse work beyond spatial reference [Moilanen, 1978]. Such uses of the adverb (mainly as a part of the 
whole German system) have been related to their counterparts in other languages (see e. g. [Blühdorn, 2003; Naumovich, 2014]).

Norwegian her, in turn, is characterized in Norsk Referansegrammatikk (NRG) as a pro-word (pro-ord) that can represent some more complex and elaborated linguistic expressions, e. g. De bor på landet - De bor her 'They live in the countryside - They live here' [Faarlund, Lie, Vannebo, 1997, p. 26]. Moreover, the item's highlighting function (den utpekende funksjonen) and expression of proximity is stressed [Faarlund et al., 1997, p. 211, 414]. The Norwegian her is said to have deictic and anaphoric function, not infrequently connected with fading of proximity in particular contexts [Faarlund et al., 1997, p. 414, 418, 1179f]. It can also be used as a kind of formal, non-nominal subject, as e. g. Her blåser forferdelig på kysten 'Here (it) blows terribly on the coast [Faarlund et al., 1997, p.681-682]. In Norwegian research, the function of her as a cohesion device is also stressed. Hilde Hasselgård, for example, notices that "original texts in English and Norwegian reveal marked differences between the two languages" as pertains to the use of HERE (representing the Norwegian her and the English here), both in the sentence-initials and other instances [Hasselgård, 2004, p. 167]. Her research claims that the item is used "more extensively as a connective device in Norwegian than in English", which she says may indicate that "spatial linking is more common in Norwegian" [Hasselgård, 2004, p. 163]. This is seen as a typical feature of this language that seems to rely on spatial linking to a greater extent than English.

On the other hand, it may be added that German is also characterized as space-oriented. In practice this means that the coding of spatial information in it is believed to be more explicit than in other languages [Blühdorn, 2002, p. 258]. The adverbial hier is claimed to play an important role in this system.

Based on the above, we might presume that the use of the two adverbials is very similar in the two languages, and - more specifically that translators most predominantly rely on the close correspondence between the two of them.

\section{METHODOLOGICAL REMARKS}

The data for the investigation presented in this article came from the Oslo Multilingual Corpus (the OMC), a parallel corpus that enabled us 
to analyze contextual uses of the deictic adverbs under investigation, occurring both as translations and sources ${ }^{1}$.

In Norwegian-to-German data, our analysis focused on the ways in which Norwegian her is rendered in translations into German as well as what German linguistic structures function as sources of her in translated Norwegian $(\mathrm{TN})^{2}$. The former are designated herein as German translations of Norwegian her, the latter as German sources of Norwegian her. The same way of investigating the data was applied, mutatis mutandis, to German-to-Norwegian translation. Namely, the analysis considered the ways in which German hier is rendered in Norwegian translations as well as what Norwegian linguistic structures function as sources of hier in translated German (designated as TD). Again, the former are described as Norwegian translations of German hier, the latter as Norwegian sources of German hier.

Correspondence is understood in this study as a technical term, defined as "what is observed in a corpus" as a result of a particular translational solution [Johansson, 2007, p. 5]. According to this framework, the correspondences identified in the corpus were classified in accordance with three criteria: direction of translation, expression, and congruence [Johansson, 2007, p. 25]. The corresponding structures were counted as zero when no formal expression of her/hier existed in the data. In terms of congruence (when the correspondence was overtly expressed by a linguistic form), two types were distinguished. Divergent correspondence was seen as based on a formal difference between the two corresponding items in the source and target text. Congruent structures, on the contrary, did not differ in form, e. g. a one-word source text expression corresponded to a one-word expression in the target language. The congruent correspondence particularly focused on in this investigation

1 The Oslo Multilingual Corpus (1999-2008), the Faculty of Humanities, University of Oslo. The OMC is a product of the interdisciplinary research project Languages in Contrast (SPRIK), directed by Stig Johansson and Cathrine Fabricius-Hansen, and compiled by the OMC corpus team (https://www.hf.uio.no/ilos/english/services/omc/ team/).

2 The abbreviations TN (translated Norwegian), TD (translated German), $\mathrm{N}$ (Norwegian in the original text), $\mathrm{D}$ (German in the original text) are displayed in the references to the corpus data, e. g. in (DG1N.3.s13) where $\mathrm{N}$ indicates that the mentioned example comes from an original Norwegian text and was translated from this language. 
was the cognate adverb - the German hier for the Norwegian her, and vice versa.

All correspondences were identified in the databases via the Glossa browser (https://tekstlab.uio.no/glossa2/omc4). They were additionally searched for manually by close reading of concordances. The starting point of the analysis was examination of the occurrences of her and hier in isolation. Subsequently, the items were analyzed in combination with each other.

In more traditional accounts, the use of her and hier is characterized as deictic (referring to the outer space) and endophoric (anaphoric and cataphoric) (see e. g. [Hasselgård 2004, p. 165f]). In the present study, a different way of treating such occurrences was applied and all of them were taken into account. Cornish posits that there is a continuum of indexicality along which particular sub-types of indexical referring procedures may be ranged; he illustrates this continuum as follows: canonical deixis $>$ discourse/text deixis $>$ (strict) anadeixis $>$ canonical discourse anaphora (see Scale of indexical referring procedures [Cornish, 2009, p. 8]).

In this view of indexicality, no clear borders between deixis and anaphora can be found and the concepts are not mutually exclusive, although it should be added that some indexical expression types can be restricted to only one type of use (e. g. I being canonically deictic and he/ she being prototypically anaphoric). Nevertheless, the majority of deictic expressions may sustain various types of use in particular contexts [Cornish, 2009, p. 12] and the items under investigation represent indexicals of this type. Therefore, in this analysis it was assumed that both the Norwegian her and the German hier "used deictically, anaphorically or anadeictically can make distinctive contributions to the structure of the discourse that may be associated with a given text in conjunction with an appropriate context" [Cornish, 2009, p. 13]. In this way, they also shape the deictic space (or frame) of discourse in the particular language. When the adverbs were applied mutually in the languages meeting in translation (her $\leftarrow \rightarrow$ hier), they were assumed to shape the deictic space in the same manner. When different correspondences to the adverbs were applied, the deictic space was assumed to be set up or construed some other way. 


\section{THE RESULTS}

Tables 1-4 below show the main findings in the conducted analyses, in Norwegian-to-German $(\mathrm{N} \rightarrow \mathrm{G})$ and German-to-Norwegian $(\mathrm{G} \rightarrow \mathrm{N})$ data:

Table 1. Correspondences to the Norwegian her in $\mathrm{N} \rightarrow \mathrm{G}$

\begin{tabular}{|l|c|c|c|c|}
\hline \multicolumn{1}{|c|}{ Correspondence } & translations & $\%$ & sources & $\%$ \\
\hline in total in $\mathrm{N} \rightarrow \mathrm{G}$ & 1353 & 100 & 1197 & 100 \\
\hline non-initial her $\rightarrow$ hier & 819 & 60.53 & 483 & 40.35 \\
\hline initial her $\rightarrow$ initial hier & 127 & 9.38 & 84 & 7.01 \\
\hline initial her $\rightarrow$ non-initial hier & 12 & 0.88 & 27 & 2.25 \\
\hline Other & 395 & 29.19 & 603 & 50.37 \\
\hline
\end{tabular}

Table 2. Other correspondences to the Norwegian her in $\mathrm{N} \rightarrow \mathrm{G}$

\begin{tabular}{|l|c|c|c|c|}
\hline & translations & $\%$ & sources & $\%$ \\
\hline In total & $\mathbf{3 9 5}$ & $\mathbf{2 9 . 1 9}$ & $\mathbf{6 0 3}$ & $\mathbf{5 0 . 3 7}$ \\
\hline ZERO & 205 & 15.15 & 329 & 27.48 \\
\hline da & 35 & 2.58 & 57 & 4.76 \\
\hline $\begin{array}{l}\text { circumstances expressed in } \\
\text { detail }\end{array}$ & 37 & 2.73 & 58 & 4.84 \\
\hline pronominal adverbs & 23 & 1.69 & 56 & 4.67 \\
\hline dort & 13 & 0.96 & 11 & 0.91 \\
\hline hier+verb & 11 & 0.81 & 6 & 0.50 \\
\hline es & 8 & 0.59 & 3 & 0.25 \\
\hline hie & 6 & 0.44 & 5 & 0.41 \\
\hline her+verb & 5 & 0.36 & 1 & 0.08 \\
\hline jetzt & 4 & 0.29 & 1 & 0.08 \\
\hline das & 3 & 0.22 & 4 & 0.33 \\
\hline nun & 2 & 0.14 & 3 & 0.33 \\
\hline
\end{tabular}


End of Table 2

\begin{tabular}{|l|c|c|c|c|}
\hline & translations & $\%$ & sources & $\%$ \\
\hline dies & 1 & 0.07 & 1 & 0.08 \\
\hline her & & & 3 & 0.33 \\
\hline hierher & & & 6 & 0.50 \\
\hline hierhin & & & 2 & 0.16 \\
\hline Other & 6 & 0.44 & 13 & 1.08 \\
\hline Excluded & 36 & 2.66 & 44 & 3.67 \\
\hline
\end{tabular}

Table 3. Correspondences to the German hier in $\mathrm{G} \rightarrow \mathrm{N}$

\begin{tabular}{|l|c|c|c|c|}
\hline \multicolumn{1}{|c|}{ Correspondence } & translations & $\%$ & sources & $\%$ \\
\hline in total in $\mathrm{G} \rightarrow \mathrm{N}$ & 509 & 100 & 1806 & 100 \\
\hline non-initial hier $\rightarrow$ her & 310 & 60.90 & 1016 & 56.25 \\
\hline initial hier $\rightarrow$ initial her & 69 & 13.55 & 138 & 7.64 \\
\hline initial hier $\rightarrow$ non-initial her & 6 & 1.17 & 26 & 1.43 \\
\hline Other & 124 & 24.36 & 626 & 34.66 \\
\hline
\end{tabular}

Table 4. Other correspondences to the German hier in $\mathrm{G} \rightarrow \mathrm{N}$

\begin{tabular}{|l|c|c|c|c|}
\hline & translations & \% & sources & $\%$ \\
\hline In total & $\mathbf{1 2 4}$ & $\mathbf{2 4 . 3 6}$ & $\mathbf{6 2 6}$ & $\mathbf{3 4 . 6 6}$ \\
\hline ZERO & 89 & 17.48 & 357 & 19.76 \\
\hline der & 6 & 1.17 & 34 & 1.88 \\
\hline $\begin{array}{l}\text { circumstances expressed in } \\
\text { detail }\end{array}$ & 9 & 1.76 & 31 & 1.71 \\
\hline denne (+N) & 5 & 0.98 & 79 & 4.37 \\
\hline herifra & 5 & 0.98 & 22 & 1.21 \\
\hline nå & 2 & 0.39 & 2 & 0.11 \\
\hline hit & 2 & 0.39 & 26 & 1.43 \\
\hline
\end{tabular}


End of Table 4

\begin{tabular}{|l|c|c|c|c|}
\hline & translations & $\%$ & sources & $\%$ \\
\hline$d a$ & 1 & 0.19 & 18 & 0.99 \\
\hline det & 1 & 0.19 & 35 & 1.93 \\
\hline pronominal adverbs & 2 & 0.39 & 6 & 0.33 \\
\hline Excluded & 2 & 0.39 & 16 & 0.88 \\
\hline
\end{tabular}

\subsection{Congruent cognate correspondences}

Table 1 and Table 3 above show the main findings pertaining to the correspondence of the cognate adverbs in Norwegian and German. In $\mathrm{N} \rightarrow \mathrm{G}$ translation, a total of 1353 occurrences of her were extracted from the corpus data, while in $\mathrm{G} \rightarrow \mathrm{N}$ translation, the data provided 509 examples. Therefore, the indexical is more frequent in Norwegian original texts than in German original texts in the OMC. Moreover, it was more frequent in German translations of Norwegian sources than vice versa $(1806 / 1197)$ a fact that also may indicate that the use of this language item as a means of building the deictic space is more popular in Norwegian.

The examples below show the typical uses of her and hier occurring as congruent cognate correspondences, in translations and sources, in $\mathrm{N} \rightarrow \mathrm{G}$ examples in (1), (2) and $\mathrm{G} \rightarrow \mathrm{N}$ examples in (3), (4).

(1) a. (N) Her trenger menneskene deg.

(G) Hier brauchen dich die Menschen. DG1N.3.s13

(N) Her slutter min fars dagboksopptegnelser,...

(G) Hier enden die Tagebucheintragungen meines Vaters, BHH1N.4.5.s1

(N) ... bystater både i Hellas og i de greske koloniene i Sør-Italia og i LilleAsia. Her gjorde slavene alt kroppsarbeidet,...

(G) ...viele Stadtstaaten in Griechenland und in ihren Kolonien in Süditalien und Kleinasien. Hier verrichteten die Sklaven alle körperliche Arbeit,... JG1N.3.1.s129

b. (N) Her bruker han ordet "Gud",...

(G) Er verwendet hier das Wort „Gott",... JG1N.4.5.s15

(N) Her spiste man ikke for å bli mett, men for å bli sett.

(G) Man aß hier nicht, um satt, sondern um gesehen $z u$ werden. OEL1N.4.s274 
c. (N) De begynner alt imorgen tidlig og får sete her på kontoret, ...

(G) Sie fangen morgen früh an und bekommen einen Tisch hier im Kontor, ... $\underline{\text { BHH1N.1.2.s162 }}$

(N) Men Aron, hva gjør du her oppe, ...

(G) Aber Aron, was machst du hier oben? BHH1N.4.2.s190

As far as $\mathrm{N} \rightarrow \mathrm{G}$ translations are concerned, the sentence-initial uses of her/hier covers the whole scale of indexical referring and may function both as deictic, anadeictic or purely discourse anaphoric. Yet strikingly, the use of sentence-initial her/hier is quite marginal in both languages. The adverbs occurred as such correspondences in $9.38 \%$ of the investigated language data, as illustrated in (1a) above. A high variety of indexical referring was also identified when the sentence-initial her was realized by its German cognate not used sentence-initially, though this occurrence, shown in (1b), also occurred very seldom (0.88\%).

This type of congruent correspondence was most frequent (over $60 \%$ of the analyzed instances) when a non-initial Norwegian her was rendered as a German non-initial hier, as illustrated in (1c).

The situation was different in the case of sources in the $\mathrm{N} \rightarrow \mathrm{G}$ data. Only $40 \%$ of the non-initial German hier sourced the occurrence of the Norwegian cognate her, used non-initially in TN, as illustrated in (2a). The other types of this congruent correspondence in TN, displayed in (2b) and (2c), were clearly infrequent $(2.25 \%$ and $7.01 \%$ respectively).

(2) a. (G) Ich habe hier in der Hand einen Käfer, behauptete er eines Tages,

(N) Jeg har denne billen her $i$ den ene hånden, kunngjorde han en dag. JH1TN.1.4.s41

b. (G) Hier wohnen einfach $z$ u viele alte Leute, ...

(N) Det bor ganske enkelt for mange gamle mennesker her. $\underline{\text { CH1TN.2.s38 }}$

c. (G) Hier hatte der große starke Aisakos gelebt?

(N) Her hadde den store, sterke Aisakos levd? CW1TN.1.s1154

As far as $\mathrm{G} \rightarrow \mathrm{N}$ is concerned, it was observed that the rendition of the German sentence-initial hier by its direct Norwegian counterpart, as in (3a) below, was higher than in $\mathrm{N} \rightarrow \mathrm{G}$ translation, accounting for $13.55 \%$. Moreover, the sentence-initial position of the German adverb was not preserved in translation into Norwegian only in $1.17 \%$ of the investigated conceptualizations, as in (3b). These facts may indicate that 
Norwegian indeed prefers this kind of conceptual linking - a fact that was confirmed in research by Hasselgård [Hasselgård, 2004]. However, as above, also in $\mathrm{G} \rightarrow \mathrm{N}$ the most frequent direct cognate correspondence was observed when hier/her were not used sentence-initially $60.9 \%$, as illustrated in (3c) below.

(3) a. (G) Hier hatte der große starke Aisakos gelebt?

(N) Her hadde den store, sterke Aisakos levd? CW1D.1.s1149

(G) Aussage heißen: „Im Durchschnitt“ sind alle Menschen auf dieser Erde satt. Hier liegt der Zynismus auf der Hand.

(N) ... Her ligger kynismen klart i dagen, UB1D.2.1.1.s19

b. (G) Hier würde ihn niemand suchen, ...

(N) Ingen ville komme på å lete etter ham her, ... ME1D.1.s257

(G) Hier sorgt er für Stütze und feine Durchgestaltung, ...

(N) Den sørger her for støtte og gjennomarbeidet form, ... UR1D.8.1.s8

c. (G) Ich hoffe, du fühlst dich hier wohl.

(N) Jeg håper du kommer til å trives her. DW1D.2.s304

(G) Aber Sie dürfen hier nicht sitzen.

(N) Men De har ikke lov til å sitte her. DW1D.2.s341

Additionally, in the case of sources in the $\mathrm{G} \rightarrow \mathrm{N}$ data, the most frequent congruent cognate correspondence $(56.25 \%)$ was identified when the Norwegian non-initial her triggered the use of the German hier used not sentence initially, as illustrated in (4a). Only $7.64 \%$ of the investigated source Norwegian sentence-initial her triggered the sentence initial hier in TD, as in (4b), and slightly $1.42 \%$ of such Norwegian sources resulted in non-initial hier, as in (4c).

(4) a. (N) Jeg er nevrolog her.

(G) Ich bin hier der Neurologe, ... OS1TD.1.2.s69

b. (N) Her, ta ham.

(G) Hier, nimm du ihn. GN1TD.1.3.s23

c. (N) Her er jeg.

(G) Ich bin hier. SK1TD.1.s128 


\subsection{Other correspondences}

Table 2 and Table 4 above show that both the Norwegian her and the German hier have a wide variety of other, both congruent and divergent correspondences, which in the $\mathrm{N} \rightarrow \mathrm{G}$ and $\mathrm{G} \rightarrow \mathrm{N}$ data account for $29.19 \%$ and $24.36 \%$ of translations, and $50.37 \%$ and $34.66 \%$ of sources, respectively. In this context, it is striking to observe that over $50 \%$ of tokens of her found in TN were triggered by other German structures, of varied form. Even more strikingly, roughly half of these $(27.48 \%$ of all cases) were zero (divergent) correspondences ${ }^{3}$, an issue that will be dealt with more closely below. Also noteworthy is that the German zero sourced both the sentence initial or non-initial her, as well as her specifying the meaning of a noun in translated Norwegian, as it is shown in (5).

(5) (G) Ich hab jede Menge Platz,...

(N) Her er nok av plass,... GN1TN.1.3.s187

(G) Wir haben vor ein paar Tagen Mr. Fibich gesehen,...

(N) Vi så herr Fibich her forleden dag. AB1TN.1.s184

(G) Die Bedienung war exzellent.

(N) Servicen her var utmerket,... AT1TN.3.s441

Because the translators felt a strong need to add her into the discourse space in situations when the German conceptualization did not include the indexical hier or other structures that may be seen as corresponding to her, it seems that Norwegian "demands" the use of the indexical in such cases. Conceptualizations of this type represented

${ }^{3}$ In both $\mathrm{N} \rightarrow \mathrm{G}$ and $\mathrm{G} \rightarrow \mathrm{N}$ data, in translations and sources, zero is the most frequent correspondence. The deictic adverb is frequently left untranslated (in translations - a) and added by the translator (in sources - b), as the examples in (i) below show. Yet, their percentage in the German sources for tokens of her in translated Norwegian (TN) is highest in the context of the conducted research. That is why they are analyzed in detail while the other zero-correspondences are only illustrated by the examples from the language data in translations (N, D) and sources (TD, TN).

(i) a. (N) Gården her er i en sørgelig forfatning,...

(G) Der Hof ist in trauriger Verfassung,... BHH1N.4.4.s780

(G) Muß hier darauf hingewiesen werden, daß Leni,...

(N) Er det nødvendig å si at Leni,... HEB1D.2.s124

b. (G) Es geht hier um Leben und Tod,...

(N) Saken gjelder liv eller $d ø d, \ldots$ BHH1TDS.1.2.s26 
various indexical referring procedures in $\mathrm{TN}$, but canonical deixis was most prominent. Moreover, TN frequently had her in combination with another spatial adverbial (one represented likewise in the German source structure), as in (6) below.

(6) (G) Sie haben eine Adresse in Frankreich?

(N) Har dere en adresse her $\underline{i \text { Frankrike? PM1TN.1.s384 }}$

(G) Ich hab praktisch einen Computer in meinem Kopf,...

(N) Jeg har faktisk en liten datamaskin her inne i hodet,... RD1TN.5.s66

(G) Nur das zählte im Leben,...

(N) det var det som tellet her $\underline{i}$ livet,... AB1TN.1.s44

In the presented examples, the Norwegian her may seem redundant as a specification of spatial circumstances. According to Hasselgård [2004, p. 171], this type of occurrence of the adverb "reinforces the proximal perspective, and furthermore contributes to cohesion through continuity of space".

The most important of the other not congruent correspondences to the Norwegian her sourced by the German structures are discussed in detail later in this paper.

Two prominent categories of such structures were branded in Table 2 and Table 4 as "circumstances expressed in detail", illustrated in (7a) below, and "pronominal adverbs", illustrated in (7b). The majority of them involved various kinds of locations (conceived syntactically as adverbials or objects in German) ${ }^{4}$.

(7) a. (G) Ich bleibe trotzdem bei ihr,...

(N) Jeg blir her likevel. AH1TN.2.1.s110

(G) Macon hatte sie bei seinem ersten Londoner Aufenthalt für so etwas wie Mikrofone gehalten,

(N) Macon hadde tatt for en slags mikrofoner første gang han var her. AT1TN.3.s426

(G) Auf diesem Stockwerk stank es,...

(N) Lukten var sterkere her. DL2TN.1.s84

${ }^{4}$ Structures of this type occur in the $\mathrm{N} \rightarrow \mathrm{G}$ data and in the $\mathrm{G} \rightarrow \mathrm{N}$ data, both in translations and sources. Yet, their occurrence is slightly more prominent in translated Norwegian (sourced by the German structure) ( $4.84 \%$ and $4.67 \%$ in Table 3 ). 
(G) Vorbild sind in dieser Hinsicht die Vereinigten Staaten,...

(N) ...forbilde er her De_forente_stater,... HME1TN.6.s85

(G) An dieser Stelle könnte alles mögliche passieren,...

(N) Her kunne flere ting skje,... ROB1TN.1.3.s1

(G) Wenn wir das Haus wieder in Ordnung gebracht haben, sind wir,...

(N) Når vi har fått ordnet opp her, så er det... DL2TN.2.s250

b. (G) Darin liegt ein wesentlicher Faktor der Krebsvorsorge,...

(N) Her har vi en vesentlig faktor når det gjelder kreftforebyggelse,... $\underline{\text { UR1TN.2.1.s78 }}$

(G) Daran ist sogar Eumelos gescheitert.

(N) Her kom selv Eumelos til kort,... CW1TN.1.s687

(G) Dabei mußte ein strikter Ehrenkodex eingehalten werden,...

(N) Her måtte en strikt areskodeks overholdes,... HME1TN.3.s46

What is important here is the fact that the correspondence based on the German pronominal adverb and the Norwegian her represents systemic differences between the languages under discussion. As it pertains to the sentence-initial position, it may be seen as a clear indicator of cohesion in discourse in both languages. However, a difference in the way how this relation is shaped may be also identified on the basis of (7a) and (7b). In this respect Norwegian and German vary in the level of specificity (schematicity), which is an important aspect of imagery [Langacker, 1987, p. 132-135]. That means that the mental pictures created in them differ in the level of delicacy, i.e. the fineness of detail, with which a situation is portrayed. The German expressions provided a finer-grained characterization of the space of discourse as regards different kinds of spatial information. In Norwegian, the same space was shaped in a more coarse-grained manner by the use of her.

\section{DISCUSSION}

A more global look at the investigated data enables us to conclude that in $\mathrm{N} \rightarrow \mathrm{G}$, the Norwegian her in total was rendered as the German hier in over $70 \%$ of the conceptualizations, in translations. In $\mathrm{G} \rightarrow \mathrm{N}$, the situation is clearly similar. The German hier, was realized as the Norwegian her in over $75 \%$ of the language data. From this first-blush obser- 
vation, a more general conclusion might be drawn that the uses of the cognate adverbs to set up the deictic space within which the discourse is to be construed in the languages under investigation are clearly similar in translation. However, the one-way analysis of this kind fails to provide a full view of the phenomenon.

In the analysis above, it was also observed that in $\mathrm{N} \rightarrow \mathrm{G}$, only $40.35 \%$ of the German sources including hier resulted in the Norwegian cognate, while the Norwegian her triggered the use of the indexical in translated German in nearly $65 \%$ of cases. These results may indicate that German exploits the possibility to "absorb" the deictic HERE-localization within its conceptual realms easily, even though the German hier cannot be seen as a trigger for profiling this location in the same manner in TN. This fact is worth noticing as it may confirm that the Norwegian her is more specialized in its use, while the meaning of the German hier may be seen as more general and easier to apply. The Norwegian indexical seems simply to demand more precise (perhaps more conventionally established) conditions of use. The question that remains is: In what respect does this happen?

Our investigation showed that even though the sentence-initial position of her in Norwegian may be seen as typical for this language, it represents a marginal phenomenon in a wider context of the item's uses in discourse, both in translations and sources. Consequently, its function as a prototypical means for expressing cohesion, i. e. providing the textual foundation for the clause as message based on spatial linking [Hasselgård, 2004, p. 163, 165] cannot be seen as predominant. As the adverbials in both languages mainly occur in non-initial position in the sentence, their function should rather be considered in more general terms as creating a deictic frame or space, within which entities of different types are located and related to the spatiotemporal co-ordinates of the act of utterance, where the speaker stands at the centre.

This possible characterization is further corroborated when other correspondences to the Norwegian adverb in TN (i. e. sourced by German structures in the $\mathrm{N} \rightarrow \mathrm{G}$ data) are taken into account. While these expressions were more detailed in conceiving the given scene, Norwegian preferred a more schematic way of portraying it, realized just by her. In this light, the meaning of her may be characterized as less locative than the meaning of structures specializing on profiling different kinds of locations (spatial or mor abstract) and conceiving the scene 
in a fine-grained manner. Therefore, explicitly expressed localization in German may be assumed to release the deictic mode in Norwegian and this mode of reference mainly implies reference to the speaker as the core of the deictic centre. Levinson describes this privileged position of the speaker very suggestively defining the origo as follows:

(i) the central person is the speaker, (ii) the central time is at which the speaker produces the utterance, (iii) the central place is the speaker's location at utterance time or CT (coding time, E. D.-B.), (iv) the discourse centre is the point which the speaker is currently at in the production of his utterance, and (v) the social centre is the speaker's social status and rank, to which the status of the addressees or referents is relative [Levinson, 1983, p. 64].

The meaning of her may be then described as "the speaker's location at utterance time or CT". Seen in this way, it is mainly speaker-centered and secondly spatial. This deictic function of setting up the subjective viewpoint or perspective within which the sentence is to be construed may be characterized as clearest in instances when in TN her occurred in combination with another spatial adverbial. Moreover, the results presented herein indicate that the deictic mode set in Norwegian by her may be characterized as stronger than in German.

One particularly striking finding that emerged from the analyses herein was the extraordinarily high percentage of zero correspondences in original German for tokens of her found in translated Norwegian $(27.48 \%$, or more than one-quarter of all such tokens; see Table 2 above). In such instances, the deictic her occurred in the translated language even though no source German trigger was involved. This somehow surprising state of affairs, which would traditionally be explained in terms of individual decisions taken by the translators, may in view of its systematicity here be seen as instead telling us something about the given languages themselves.

The phenomenon may be interpreted with reference to the gravitational-pull hypothesis, which situates translation within the context of most recent knowledge on bilingual cognition and helps to explain how semantic structures work in translation [Halverson, 2003; 2017]. According to this hypotheses, highly salient (lexical and grammatical) structures exert a certain gravitational pull during the cognitive process of translation, resulting in an overrepresentation of specific target language (TL) structures that correspond to those salient configurations 
in the schematic network in the speakers' bilingual minds [Halverson, 2003, p.218]. In the context of the source language, this type of pull means "copying" of such structures into the TL, as it was e. g. conceived in the law of interference formulated by Gideon Toury (see [Toury, 1995]). In the context of the target language, however, the gravitational pull means "magnetism", based on an assumption that "in the cognitive search for a target language item, the translator is more likely to be drawn to a target language item with high salience" [Halverson, 2017, p. 14] - a mechanism that in other words may be described as: what is notionally salient in the TL may be expected to be chosen in translation into this language first and in high extent (as e. g. Toury's law of growing standardization claims $)^{5}$.

Applying this mechanism to our zero correspondences in German for tokens of the Norwegian her found in in TN, it may be stated that the "magnetism" of Norwegian to signal the presence of the deictic herspace is strong, as the structure was added by the translators in over $27 \%$ of conceptualizations, even though no trigger in the source language was present. Moreover, it may be assumed to be stronger than in the case of the German hier, as zero correspondences in Norwegian sources pertained to $19.76 \%$ of tokens of this item found in TD (see Table 4 above).

Discussion of this issue may be further enriched by the application of a Cognitive Grammar account. From this perspective, the differences in use of the Norwegian her and the German hier, proved in the investigation, may be explained in terms of degrees of subjectivity, which has its roots in basic human spatial and visual experience.

According to Langacker (e. g. [Langacker, 1985; 1987; 1995]), a canonical viewing arrangement maximizes the asymmetry between the role of a viewer, as the subject of perception, and the role of the object of perception (the perceived situation). The same pertains to linguistic conceptualizations. In such cases the role of the viewer (the conceptualizer, the speaker) is constructed as maximally subjective, that of the object as maximally objective. According to this asymmetry that underlies the concept of subjectivity, the conceptualizer $(\mathrm{C})$ remains offstage,

${ }^{5}$ Seen from this perspective, the zero correspondence in sources may be postulated to indicate the strength of magnetism in translation - as a measure indicating to what extent a particular language structure occurs as salient in the bilingual representation in a translation task. 
functioning as the subject of conceptualization, while the object (i.e. the profile of the expression) is focused on. It is then said that the conceptualizer is construed subjectively, and the profile objectively, as e.g. in Anna is happy.

However, the canonical asymmetry may be lessened "by directing our gaze so as to bring a portion of our own body into VF (viewing frame, E.D.-B.) as the focus of attention" [Langacker, 1995, p. 162]. The conceptualizer himself may also go onstage as the focus of attention and consequently as the profile of the linguistic conceptualization, which happens, for instance, when the deictic pronoun I, as in I am happy, is used. Moreover, the focus of attention may encompass other parts of the conceptualizer, e. g. his location in space, time, etc. In this so-called egocentric viewing arrangement, the profile of the linguistic expression includes some aspects of the functioning of the conceptualizer.

The concept of viewing and subjectivity may be applied in the context of deixis. The origo or the ground, defined as $I$, here, now and you are seen as important reference points in establishing communication. Usually they remain offstage and function as the subjects of the conceptualization, but they may be also put onstage (profiled by linguistic expressions), e. g. as in I can see you better now. In such cases, the ground is construed objectively and it may be involved within the profile to different degrees [Langacker, 1995, p.171, 172]. The same happens each time when here and its cognates, the Norwegian her and the German hier, are used within an expression.

The concept of subjectivity is, as Langacker [1985, p. 109] expresses it, "both subtle and complex". Its presence in the functioning of each language is fundamental. Yet, languages may vary with respect to which types of subjectivity they apply in their structures [Langacker, 1985]. Moreover, little is known to what extent they show similarities and differences in this respect. Nevertheless, applying the concept to the linguistic data may enable us to reveal how the languages differ in construing the ground.

The differences in the use of the Norwegian her and the German hier (especially in $\mathrm{N} \rightarrow \mathrm{G}$ data on sources), as disclosed in our investigation and discussed partly above, may also be indicative of different ways by which the ground is constructed in these languages and consequently of differences in subjectivity. More than $50 \%$ of the tokens of the indexical her in TN were sourced by German structures other than hier, of varied 
form (shown in Table 3 and represented by zero correspondence, circumstances expressed in detail or pronominal adverbs, etc.), signaling that in Norwegian the speaker often indicates explicitly that the events concerned are connected with him/herself. The space "including" him/ herself thus tends to be put onstage, while in German other aspects of the situation tend to be profiled. In this way the role of the speaker connected with the deictic location is objectified in Norwegian, causing the subjectivity to occur to a greater degree as compared to German $(34.66 \%)$. In other words, the reinforced Norwegian deictic discourse space was more speaker-centered.

Thus, from the perspective of CG, Norwegian may be seen as the somewhat more egocentric sister of the two closely related languages, which in many respects show very clear grammatical similarities and even evident similarities in the use of the cognate indexicals her/hier. This difference pertains to how speakers set up the viewpoint or perspective within which discourse is to be construed and hence constructed - with a greater degree of objectification of the conceptualizer and his/her parts in Norwegian than in German.

\section{CONCLUSIONS}

In terms of methodology, this investigation has demonstrated that the use of a parallel corpus can broaden the research perspective in insightful ways and help to elaborate upon and deepen our first observations of the linguistic data. This is perhaps especially true for the examination of subtleties in the use of close cognates in closely related languages - in this case pertaining to the more frequent use of the indexical her in Norwegian as compared to its cognate hier in German. Considering exclusively translations of her/hier as data, as we have shown, fails to capture certain differences in the conceptualization of deictic space in these two languages. Rather, also looking at the data on the sources of tokens of her/hier found in translated Norwegian and translated German allowed us to bring such differences in imagery between the two languages into clearer relief. As far as the particular correspondences among these sources are concerned, we have argued that they may be characterized in terms of greater magnetism on the part of Norwegian towards expressing deixis by the use of the indexical her, and/or in terms of a lower level of specificity in conceiving the spatial 
a)

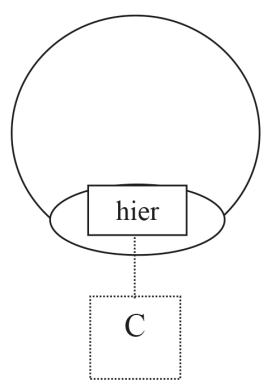

b)

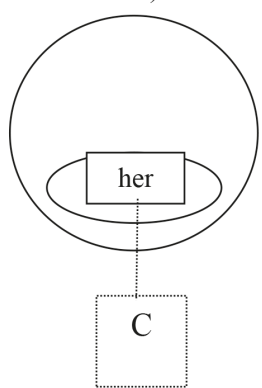

Fig. Degrees of subjectivity in the construction of the discourse space in German (a) and Norwegian (b)

information in discourse. The main and most obvious difference found in setting up the deictic space pertains, however, to the viewpoint construal that is preferred in Norwegian and German - a more egocentric one in the former language, and one more subjective and focused on the object of conceptualization in the latter, as shown in figure below.

Thus, as the example serves to show, differences in imagery in two languages may be based on different vantage points that are preferred in them and result in some clear patterns of construal that influence linguistic conceptualizations on a lower level (e.g. as regards cohesion, specificity, distance, etc.)

In a wider research context, analysis within the framework of CG enables us also to shed some new light on certain characteristics of the indexicals her and hier that have been mentioned in the literature. Firstly, Norwegian seems less space-oriented than German, which to a greater extent prefers explicit, detailed spatial indication within the discourse space. Moreover, the sentence-initial her, which without doubt is a clear device of cohesion in Norwegian, expresses it not relying on spatial linking but on deictic grounds, through the application of different types of indexical referring procedures, in which the role of the speaker is clearly involved. Also, the view on the proximity expressed by the adverbials may be modified if the observed differences in imagery in Norwegian and German are zoomed in on. The German perspective, which is connected with the fine-grained portrayal of spatial information, paradoxically implies a more distant point of view (re- 
sembling the canonical viewing arrangement), than the one that results in seeing the same scene as more coarse-grained (i. e. not including the details) - a viewing experience that occurs if we approach a perceived scene too closely. The German hier may be therefore characterized as less proximal than the proximal her. It seems, then, as if the Norwegian conceptualizer feels "culturally obligated" to come to the scene so close that $\mathrm{s} /$ he is unable to see nothing more than his/her own location. To what extent such an analysis can be sustained for Norwegian in a more general sense is - we suggest in closing - a worthwhile subject for future investigation.

\section{REFERENCES}

Blühdorn H. Rauminformation and Demonstrativität. Am Beispiel des Deutschen. Deutsche Sprache 3, 2002. P. 252-275.

Blühdorn H. Die Raumadverbien hier, da und dort und ihre Entsprechungen im brasilianischen Portugiesisch. Die kleineren Wortarten im Sprachvergleich Deutsch - Portugiesisch. Eds H. Blühdorn, J.Schmidt-Radefeldt. Frankfurt am Main: Peter Lang, 2003. P. 47-72.

Bühler K. Sprachtheorie. Die Darstellungsfunktion der Sprache. Jena: Gustav Fischer, $1934.434 \mathrm{p}$.

Cornish F. Indexicality by degrees: Deixis, 'anadeixis', and (discourse) anaphora. Symposium "Quel sens pour la linguistique?" organised to mark the award of docteur honoris causa to Professor Sir John Lyons, Université de Toulouse-Le Mirail, 23 $3^{\text {rd }}-24^{\text {th }}$ April 2009. 2009. HAL Id: hal-00960772 P.1-15. Available at: https://hal-univ-tlse2.archives-ouvertes.fr/hal-00960772 (accessed: 11.02.2020)

Ehrich V. Da and the System of Spatial Deixis in German. Pragmatics and Beyond 3, 1982. P. 43-63.

Ehrich V. Hier und jetzt: Studien zur lokalen und temporalen Deixis im Deutschen. Tübingen: Niemeyer, 1992. 194 p.

Faarlund J. T., Lie S., Vannebo K. I. Norsk referansegrammatikk. Oslo: Universitetsforlaget, 2002. $1223 \mathrm{p}$.

Halverson S. The cognitive basis of translation universals. Target 15 (2), 2003. P. 197-241.

Halverson S. Gravitational pull in translation: Testing a revised model. Empirical Translation Studies: New Methodological and Theoretical Traditions. Eds G. De Sutter, M.-A. Lefer, I. Delaere. Berlin: De Gruyter, 2017. P.9-33.

Hasselgård H. Spatial linking in English and Norwegian. Translation and Corpora. Selected Papers from the Göteborg-Oslo Symposium 18-19 October 2003. Eds K. Aijmer, H. Hasselgård. Göteborg: Acta Universitatis Gothoburgensis, 2004. P. 9-33 
Helbig G., Buscha J. Deutsche Grammatik. Ein Handbuch für den Ausländerunterricht. Leipzig: VEB Verlag, 1988. 737 p.

Johansson S. Seeing Through Multilingual Corpora: On the Use of Corpora in Contrastive Studies. Amsterdam: John Benjamins, 2007. 355 p.

Klein, W. Wo ist hier? Präliminarien zu einer Untersuchung der lokalen Deixis. Linguistische Berichte 58, 1978. P. 18-40.

Kryk-Kastovsky B. The linguistic, cognitive and cultural variables of the conceptualization of space. The Construal of Space in Language and Thought. Eds M. Pütz, R. Dirven. Berlin; New York: Mouton de Gruyter, 1996. P. 329-344.

Langacker R.W. Observations and Speculations on Subjectivity. Iconicity in Syntax. Ed. by J.Haiman. Amsterdam; Philadelphia: John Benjamins, 1985. P. $109-150$

Langacker R. W. Foundations of cognitive grammar. Volume I: Theoretical Prerequisites. Stanford: Stanford University Press, 1987. 540 p.

Langacker R. W. Viewing in Cognition and Grammar. Alternative Linguistics. Descriptive and Theoretical Modes. Ed. by P. W. Davis. Amsterdam; Philadelphia: John Benjamins, 1995. P. 153-212.

Levinson S. Pragmatics. Cambridge: Cambridge University Press, 1983. 420 p.

Lyons J. Semantics (Vol 1\&2). Cambridge: Cambridge University Press, 1977. $897 \mathrm{p}$.

Marmaridou S. Pragmatic Meaning and Cognition. Amsterdam: Benjamins, 2000. $322 \mathrm{p}$.

Moilanen M. Zur pragmatischen Funktionen der Demonstrativadverbien hier, da und dort. Die Partikeln der deutschen Sprache. Ed. by H. Weydt. Berlin: De Gruyter, 1978. P. 187-200.

Naumovich V. Die deiktischen Ausdrücke hier, da, dort und ihre russischen Entsprechungen. Eine empirische Untersuchung an Pressetexten. Berlin: LIT Verlag, 2014. $256 \mathrm{p}$.

Tabakowska E. Cognitive Linguistics and Poetics of Translation. Tübingen: Gunter Narr Verlag, 1993. 146 p.

Toury G. Descriptive Translation Studies and Beyond. Amsterdam; Philadelphia: John Benjamins, 1995. 311 p.

\section{Эва Дата-Буковска}

Ягеллонский университет, Краков

\section{ЧУТЬ БОЛЕЕ ЭГОЦЕНТРИЧНАЯ СЕСТРА: ПРОСТРАНСТВЕННЫЙ ДЕЙКСИС НОРВЕЖСКОГО НЕR И НЕМЕЦКОГО НІЕR С ПОЗИЦИИ КОГНИТИВНОЙ ГРАММАТИКИ}

Для цитирования: Data-Bukowska E. A somewhat more egocentric sister: A cognitive grammar account of Norwegian her and German hier as deictic space builders // Скандинавская филология. 2020. Т. 18. Вып. 1. С. 32-55.

https://doi.org/10.21638/11701/spbu21.2020.103 
В настоящей статье рассматриваются данные из параллельного корпуса (Многоязычный корпус Осло) с целью изучения различий использования родственных норвежских и немецких наречий her/hier «здесь» (по-видимому, очень близких по смыслу) как конструктов дейктического пространства в дискурсе. Цель представленного исследования - предложить некоторые более общие когнитивные механизмы, которые могут лежать в основе таких различий в близкородственных языках. Лингвистический материал рассматривается в рамках когнитивной грамматики и связан с последними знаниями о билингвальном познании, представленными в переводе. Тщательно изучая как источники, так и переводы этих наречий в корпусе переводов, мы выявляем различные образцы конструала в сравниваемых языках. Основное различие, обнаруженное при настройке дейктического пространства, касается системы координат (то есть origo), предпочтительной в норвежском и немецком языках - более эгоцентрической в первом и более субъективной и ориентированной на объект концептуализации во втором. Таким образом, тщательное изучение того, как ведут себя два родственных языка в переводе, помогает нам подтвердить, что различия в изображениях на двух языках могут основываться на предпочтении разных точек зрения, а это в свою очередь приводит к определенным шаблонам концептуализации на более низком уровне, и изображения зависят от выбора конкретных культур. Кроме того, продемонстрировано, что норвежский язык кажется менее ориентированным на пространство, чем немецкий, который в большей степени предпочитает детальную пространственную индикацию в дискурсе, и что немецкое hier предположительно может быть менее проксимальным, чем проксимальное her.

Ключевые слова: когнаты, дейксис, индексичные выражения, когнитивная грамматика, субъективность, перспектива, конструкты пространства, параллельный корпус, норвежское her, немецкое hier.

\section{Ewa Data-Bukowska}

Assistant Professor, Jagiellonian University in Kraków, Al. Mickiewicza 9A, 31-120 Kraków, Poland

E-mail: ewa.data-bukowska@uj.edu.pl 